\title{
Active compounds and biological activity of in vitro cultures of some Echinacea purpurea varieties
}

\author{
Mohamed Ramadan Rady ${ }^{1 *}$ (D) Ahmed M. Aboul-Enein ${ }^{2}$ and Mona Mohamed Ibrahim
}

\begin{abstract}
Background: Plant cell cultures have developed rapidly in recent years for the synthesis of selected natural products. This study was conducted to evaluate the effect of yeast extract, jasmonic acid, phenylalanine, and tyrosine on total caffeic acid and polysaccharide production in callus cultures of two Echinacea varieties, namely Double Decker and Rubinstern. The biological activities (antioxidant, antimicrobial and cytotoxic activities) of different Echinacea extracts were also evaluated.
\end{abstract}

Results: Data revealed the effect of yeast extract on calli of the two varieties. Double Decker calli recorded maximum caffeic acid derivatives and total hydrolysable sugars after 30 days of cultivation using $1.5 \mathrm{~g} / \mathrm{l}$ and $1.0 \mathrm{~g} / \mathrm{l}$ yeast extract respectively whereas, in Rubinstern calli, the maximum caffeic acid derivatives and total hydrolysable sugars were recorded at $1.0 \mathrm{~g} / \mathrm{l}$ after 30 days. Using $50 \mathrm{mM}$ jasmonic acid, Double Decker calli recorded maximum values of caffeic acid derivatives and total hydrolysable sugars after 15 days. In Rubinstern calli, caffeic acid derivatives and total hydrolysable sugar recorded maximum values after 30 days at $200 \mathrm{mM}$ jasmonic acid and after 15 days at $50 \mathrm{mM}$ jasmonic acid, respectively. In Double Decker variety, caffeic acid derivatives and total hydrolysable sugars recorded maximum values at $100 \mathrm{mg} / \mathrm{l}$ phenylalanine. Rubinstern calli recorded maximum value of caffeic acid derivatives at $100 \mathrm{mg} / \mathrm{l}$ phenylalanine and total hydrolysable sugars at $50 \mathrm{mg} / \mathrm{l}$ phenylalanine. As for tyrosine, maximum values of caffeic acid derivatives and total hydrolysable sugars recorded at $150 \mathrm{mg} / \mathrm{l}$ with Double Decker calli. Rubinstern calli recorded maximum value of caffeic acid derivatives and total hydrolysable sugars at 150 and $50 \mathrm{mg} / \mathrm{l}$ tyrosine, respectively. The biological activities of the different Echinacea extracts showed that maximum antioxidant activity (89.2\%) was recorded with Rubinstern calli. Also, the maximum value of cell death (78.2\%) was observed with the extract of Rubinstern calli. For antibacterial activity, most extracts showed inhibitory effect against Bacillus subtilis and Staphylococcus aureus growth.

Conclusion: Both elicitors (yeast extract and jasmonic acid) and precursors (phenylalanine and tyrosine) have a clear effect on natural products of the two Echinacea varieties. The investigated Echinacea extracts (in vitro and in vivo plants and calli of the two varieties) showed moderate activity against tested microbial strains.

Keywords: Echinacea purpurea, Cell culture, Elicitation, Caffeic acid, Polysaccharide, Antioxidant, Antimicrobial

\footnotetext{
*Correspondence: drrady1@yahoo.com

'Plant Biotechnology Department, National Research Centre, P.O. 12622,

Dokki, Giza, Egypt

Full list of author information is available at the end of the article
} 


\section{Background}

The Echinacea species, known as purple coneflower, belongs to Asteraceae family and is native to North America. Echinacea have a long history of medicinal use for a variety of conditions in North America, and currently, Echinacea products are among the best-selling herbal medicines in several developed countries (Percival 2000). Echinacea products also constitute a significant portion of the growing multi-billion-dollar pharma industry. The pharmacological activity of Echinacea extracts has been widely studied, with over 350 published studies to date (Briskin 2000).

Alkamides, caffeic acid derivatives and polysaccharides are the principal phytochemical constituents of Echinacea extracts (Bauer 1998). The potential active compounds of Echinacea are caffeic acid derivatives (CADs) such as cichoric acid, chlorogenic acid and caffeic acid have been identified in Echinacea species. Cichoric acid (a major compound in Echinacea purpurea) exhibits phagocytic, antihyaluronidase activity (Bergeron et al. 2002) and immunostimulatory properties (Choffe et al. 2000). It has also shown to inhibit HIV-1 integrase and replication (Lin et al. 1999). The potential active compounds in Echinacea including CADs, alkamides, polysaccharides and glycoproteins exhibit various clinical effects such as antioxidative, antibacterial, antifungal properties and are also used for treating common cold and respiratory and urinary diseases (Barrett 2003).

The plant E. purpurea was also found to possess antimicrobial activity. The extracts of $E$. purpurea roots inhibited the growth of two kinds of yeast (Candida sp. and Saccharomyces cerevisiae) (Binns et al. 2000; Merali et al. 2003).

As Echinacea is a good source of caffeic acid derivatives, alkamides, polyacetylenes, glycoproteins and polysaccharides, it can also be used as a model system to study factors that influence the production of these compounds ( $\mathrm{Hu}$ et al. 2004). Today preparations of Echinacea species are used as herbal drugs worldwide. These preparations contain different mixtures of various forms of Echinacea, both alone and in combination with other substances (Lienert et al. 1998; Bauer 1999).

Conventional propagation of Echinacea employs seeds, crown divisions and root cuttings (Miller 2000). Seeds are directly sown in the field or germinated in the greenhouse, and the established seedlings are then transplanted in the field (Miller 2000). However, the efficiency of Echinacea seed germination and transplant production is rather low and inconsistent, ranging from no germination to variable frequency depending on the physiology of the seeds, and the growth environment, soil pH and moisture (Hobbs 1998; Macchia et al. 2001). Echinacea seed dormancy also varies with species (Li 1998); Echinacea pallida and Echinacea angustifolia exhibit higher levels of dormancy than E. purpurea (Hobbs 1998). Although propagation by seed in Echinacea is a predominant technique, it does not ensure pathogen-free plants. It is seasonal dependency, time-consuming and prone to poor yield because of seed dormancy and diseases.

Cell cultures and their elicitation may be a promising way of finding novel compounds, offering an opportunity of creating molecular diversity in nature. To fulfill the increasing demand for this important medicinal plant, different methods and strategies have been developed, which include rapid multiplication of axenic, healthy plants and faster introduction of new cultivars with desired traits (Abbasi et al. 2007). In this regard, in vitro tissue culture techniques are proved to be very valuable. Therefore, different authors have been using the tissue culture techniques for $E$. purpurea plant and investigated the production of active compounds from propagated plants or cell cultures. The in vitro grown cells, callus and hairy root cultures were used to study biosynthetic pathways of important phytochemicals in Echinacea (Hu et al. 2004). Echinacea cell cultures have been successfully used for small- and large-scale production of polysaccharides (Misawa 1994; Li and Barz 2005). Also, cinnamic acid and caffeic acid were isolated from callus cultures of Echinacea (Sicha et al. 1991). In this concern, we investigated in vitro clonal propagation for caffeic acid production in addition to RAPD analysis of some varieties of E. purpurea plants (Aboul-Enein et al. 2013).

In this study, callus cultures from different explants of two varieties of E. purpurea, Double Decker and Rubinstern, were established and the effect of two precursors (phenylalanine and tyrosine) and two elicitor compounds (yeast extract and jasmonic acid) on production of caffeic acid derivatives and hydrolysable sugars was studied. Antioxidant, antitumor and antimicrobial properties of in vitro plants and callus cultures of Rubinstern and Double Decker varieties in comparison with in vivo plants were also investigated.

\section{Methods \\ Plant materials}

Seeds of the two varieties of Echinacea (Rubinstern and Double Decker) were kindly supplied by SEKEM Company, Egypt.

\section{Seed sterilization and germination}

Seeds of the Echinacea varieties were sterilized using $70 \%$ commercial solution Clorox (containing 5.25\% sodium hypochlorite) for $20 \mathrm{~min}$, rinsed thoroughly with sterile distilled water seven times and germinated aseptically on basal medium (MS-medium) Murashige and Skoog (1962). 


\section{Culture medium and culture condition}

The MS medium contained 3\% sucrose and was solidified with $0.7 \%$ agar. The $\mathrm{pH}$ of the medium was adjusted to 5.8 and autoclaved at $121^{\circ} \mathrm{C}$ for $25 \mathrm{~min}$. The cultures were incubated in a growth chamber at $26 \pm 1{ }^{\circ} \mathrm{C}$ under $16 \mathrm{~h}$ photoperiod. After 1 month, seedlings have reached about 1-3 cm in height and were used as starting plant material to excise different explants.

\section{Callus initiation and maintenance}

Leaf and shoot tip explants were obtained from in vitro germinated 4-week-old seedlings of the two Echinacea varieties (Rubinstern and Double Decker). The explants were placed onto MS-medium supplemented with different combinations of naphthalene acetic acid (NAA) (0.0, $0.25,0.50$ and $1.0 \mathrm{mg} / \mathrm{l})$ with benzyl adenine (BA) $(0.0$ and $0.5 \mathrm{mg} / \mathrm{l})$. The cultures were incubated at $26 \pm 1{ }^{\circ} \mathrm{C}$ for $16 \mathrm{~h}$ photoperiod. The percentage of callusing and number of formed shoots/explant were evaluated after 4 weeks of cultivation. After callus initiation, the produced calli of Rubinstern and Double Decker Echinacea varieties were transferred onto the production media containing different concentrations of $\mathrm{BA}(2.5,5.0$ and $7.5 \mathrm{mg} / \mathrm{l})$ and $0.2 \mathrm{mg} / \mathrm{l}$ NAA to obtain mass production of callus.

\section{Effect of elicitors on the active components}

Calli produced from Rubinstern and Double Decker varieties were grown onto production medium supplemented with different concentrations of yeast extract $(0.5,1.0$ and $1.5 \mathrm{~g} / \mathrm{l})$ or different concentrations of jasmonic acid (50, 100 and $200 \mathrm{mM}$ ). The cultures were grown at $26{ }^{\circ} \mathrm{C} \pm 1$ under light condition of 16 h photoperiod in a growth chamber for 3 months. Subculturing of the callus was done after every 4-week interval. Total caffeic acid derivatives and total hydrolysable sugars were determined in calli obtained after 15 and 30 days of cultivation.

\section{Effect of precursors feeding on the active components}

Callus produced from Rubinstern variety and Double Decker variety was grown onto MS-medium containing $0.2 \mathrm{mg} / \mathrm{l} \mathrm{NAA}+5.0 \mathrm{mg} / \mathrm{l}$ BA (callus production medium) and supplemented with different concentrations of phenylalanine $(50,100$ and $150 \mathrm{mg} / \mathrm{l})$ or three concentrations of tyrosine $(50,100$ and $150 \mathrm{mg} / \mathrm{l})$. The cultures were maintained at $26 \pm 1{ }^{\circ} \mathrm{C}$ temperature, and $16 \mathrm{~h}$ photoperiod in a growth chamber for 3 months, subculturing of the callus was done every 4-week intervals. After 3 months, the calli were taken for determination of total caffeic acid derivatives and total hydrolysable sugars.

\section{In vitro and in vivo plants}

In vitro plants of Rubinstern and Double Decker Echinacea varieties (Fig. 1) were obtained using shoot tip and leaf explants. Optimum shoot multiplication was observed on MS-medium containing $0.5 \mathrm{mg} / \mathrm{L} \mathrm{BA}$ for the two varieties. Rooting were obtained with MS-basal medium or MS with IBA. In vivo plants were obtained from growing seeds in greenhouse (Aboul-Enein et al. 2013).

\section{Total caffeic acid derivative determination}

Total caffeic acid derivatives were determined in the dried callus tissues (dried in oven at $60{ }^{\circ} \mathrm{C}$ for $24 \mathrm{~h}$ ) according to Bauer et al. (1988). The absorbance was read at $330 \mathrm{~nm}$ against chicoric acid which was used for standard curve preparation.

\section{Total hydrolysable sugar determination}

The total hydrolysable sugars were determined in the dried callus tissues according to Dubois et al. (1956). The absorbance of the developed yellow-orange color was measured at $490 \mathrm{~nm}$. A standard curve was carried out using pure glucose with a suitable concentration.

\section{Biological activities of Echinacea varieties Extract preparation}

About $2 \mathrm{~g}$ of the dried samples of the in vitro plants, in vivo plants and calli of Rubinstern and Double Decker varieties were extracted using a method of maceration with $80 \%$ methanol for $3 \mathrm{~h}$ at room temperature. After the maceration, the extracts were collected, filtered and evaporated to dryness. The residues were dissolved in methanol $(80 \%)$ and stored at $4{ }^{\circ} \mathrm{C}$ until further use (Pellati et al. 2004).

\section{Antioxidant activity}

The radical scavenging capacity (RSC) of Echinacea crude extracts was performed by using DPPH (2,2-diphenyl-1-picrylhydrazyl) assay. The free radical scavenging capacity percentage (RSC\%) was assayed

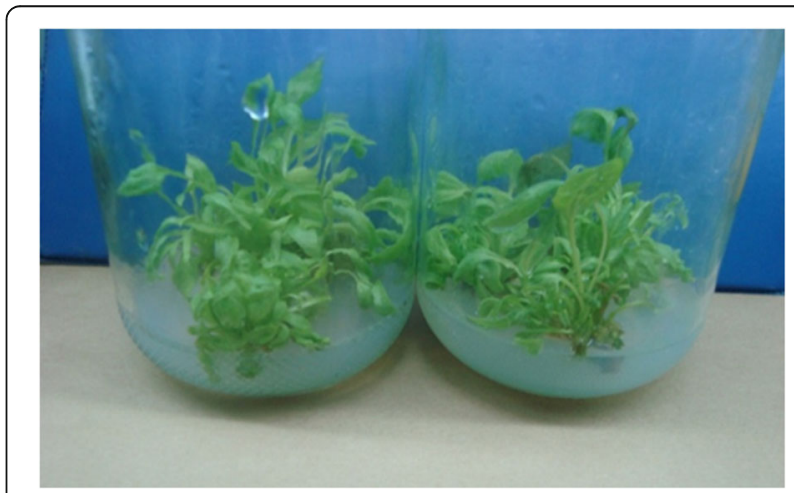

Fig. 1 In vitro plantlets of Rubinstern and Double Decker varieties 
according to Brand-Williams et al. (1995). After 15, 30, 45 , and $60 \mathrm{~min}$ of incubation, the absorbance of the samples and the control were measured at $515 \mathrm{~nm}$ using a spectrophotometer. The capability to scavenge the DPPH radical was calculated using following equation:

Radical scavenging capacity percentage (RSC\%)

$=\left[\left(\mathrm{A}_{515}\right.\right.$ of control $-\mathrm{A}_{515}$ of sample $) / \mathrm{A}_{515}$ of control $] \times 100$.

where $\mathrm{A}=$ absorbance at $515 \mathrm{~nm}$.

\section{Cytotoxic activity}

The cytotoxic activity of different Echinacea extracts was performed using the viability of tumor cells percentages which was measured by cytotoxic trypan blue exclusion technique as described by Bennett et al. (1976).

\section{Antimicrobial activity}

Three kinds of pure strains of bacteria (Bacillus subtilis-NRRL-B941(G+), Staphylococcus aureus (G+), Escherichia coli-NRR-B3704(G-), and two strains of yeasts (S. cerevisiae and Candida albicans) were used in this experiment. The bacterial stock cultures were maintained at $4{ }^{\circ} \mathrm{C}$, and the antimicrobial activity was measured as described by Harrigan and Mc-Cance (1976). This assay was carried out using well diffusion method against the used microbial pathogen cultures. Inhibition zone diameter $(\mathrm{cm})$ was measured after $24 \mathrm{~h}$.

\section{Statistical analysis}

LSD (least squares differences) test was used to compose the significant differences between means of treatment (Waller and Duncan 1969).

\section{Results}

\section{Callus initiation}

Two different explants (leaf and shoot tip) of two Echinacea varieties (Rubinstern and Double Decker) were used for inducing callus cultures. Results in Table 1 show the effect of different NAA and BA combinations on morphogenic response of both explants of the two varieties used. It could be observed that all combinations of NAA and BA induced calli from both explants except MS-medium, free of growth regulators with the two Echinacea varieties after 4 weeks of cultivation.

It could be observed that MS-medium supplemented with $0.5 \mathrm{mg} / \mathrm{l}$ each of NAA and BA gave the highest percentage of callus initiation (86\%) from leaf explants of Rubinstern variety. While in Double Decker variety, the medium containing $1 \mathrm{mg} / \mathrm{l} \mathrm{NAA}$ and $0.5 \mathrm{mg} / \mathrm{l} \mathrm{BA}$ gave the best callus initiation. Using shoot-tip explants, the highest callus initiation (100\%) was found at all levels of NAA and BA especially when grown on MS-medium supplemented with $0.25 \mathrm{mg} / \mathrm{l} \mathrm{NAA}+0.50 \mathrm{mg} / \mathrm{l} \mathrm{BA}$ (Fig. 2). However, no response was observed using medium without growth regulators. In general, shoot tip explants are better responsive than leaf explants for callus initiation for the two varieties.

Data in Table 1 also show that the highest number of shoots/leaf explants (1.00 and 0.66) was recorded in Double Decker and Rubinstern varieties, respectively. However, medium containing NAA $(0.5 \mathrm{mg} / \mathrm{l})$ and BA $(0.5 \mathrm{mg} / \mathrm{l})$ induced the highest number of shoots $(2.0)$ from shoot-tip explants of Rubinstern variety. On the other hand, no shoot formation was observed in Double Decker variety in all tested media, while shoot formation was observed with leaf explant.

\section{Effect of elicitors on the active components}

Two important elicitor compounds (yeast extract and jasmonic acid) were used to obtain high productivity of the active compounds in Double Decker and Rubinstern Echinacea calli derived from shoot-tip explants.

\section{Effect of yeast extract}

Data in Table 2 show that total content of caffeic acid derivatives in Double Decker calli increased gradually after 15 and 30 days with increasing yeast extract

Table 1 Morphogenic response of different explants of two Echinacea varieties cultured on MS-medium supplemented with different combinations of NAA and BA after 4 weeks of cultivation

\begin{tabular}{|c|c|c|c|c|c|c|}
\hline \multirow[t]{2}{*}{ Var. } & \multicolumn{2}{|c|}{ NAA BA (mg/l) } & \multicolumn{2}{|l|}{ Leaves } & \multicolumn{2}{|l|}{ Shoot tips } \\
\hline & & & Callus initiation (\%) & No. of shoot/exp. & Callus initiation (\%) & No. of shoot/exp. \\
\hline \multirow[t]{4}{*}{ Rubinstern } & 0.00 & 0.00 & 0 & 0.00 & 0 & 0.00 \\
\hline & 0.25 & 0.50 & 60 & 0.00 & 100 & 0.67 \\
\hline & 0.50 & 0.50 & 86 & 0.57 & 100 & 2.00 \\
\hline & 1.0 & 0.50 & 86 & 0.66 & 100 & 0.83 \\
\hline \multirow[t]{4}{*}{ Double Decker } & 0.00 & 0.00 & 0 & 0.00 & 0 & 0.00 \\
\hline & 0.25 & 0.50 & 67 & 0.33 & 100 & 0.00 \\
\hline & 0.50 & 0.50 & 86 & 0.29 & 100 & 0.00 \\
\hline & 1.0 & 0.50 & 100 & 1.00 & 100 & 0.00 \\
\hline
\end{tabular}




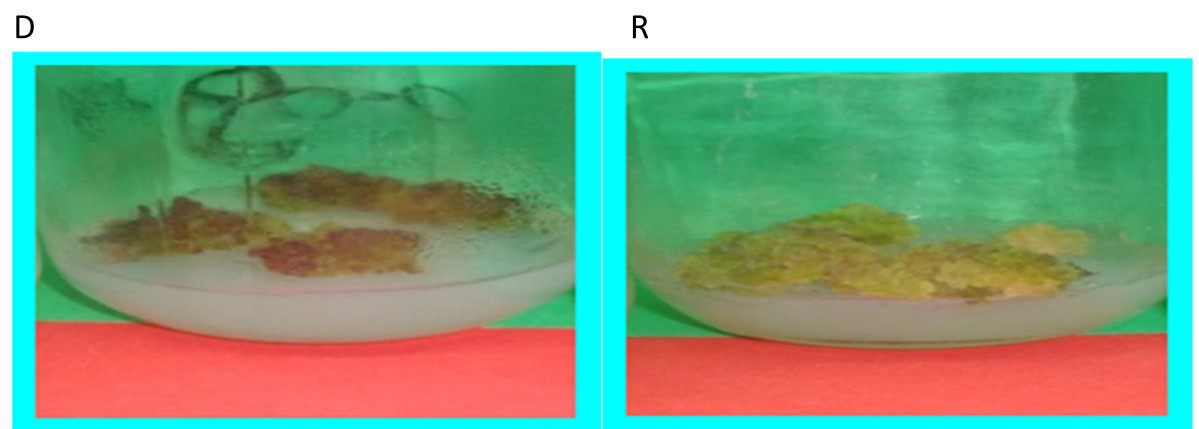

Fig. 2 Calli of Double Decker (D) and Rubinstern (R) varieties from shoot-tip explants on MS-medium supplemented with 0.25 mg/l NAA + 0.50 mg/l BA

concentration. There are significant differences between the control and all treatments $(0.5,1.0$ and $1.5 \mathrm{~g} / \mathrm{l}$ yeast extract). The highest content of caffeic acid derivatives was obtained after 15 and 30 days $(2.38$ and $3.66 \mathrm{mg} / \mathrm{g} \mathrm{DW}$ respectively) at a level of $1.5 \mathrm{~g} / \mathrm{l}$ yeast extract. Also, all tested concentrations of yeast extract significantly increased caffeic acid content in Rubinstern calli after 15 and 30 days; the maximum values (1.87 and $2.26 \mathrm{mg} / \mathrm{g} \mathrm{DW})$ were obtained after 15 and 30 days respectively at a level of $1.0 \mathrm{~g} / \mathrm{l}$ yeast extract. There was nearly $3.2-$ and 2.6 -fold increase, respectively for Rubinstern variety and 2.93- and 2.16-fold increase for Double Decker variety after 15 and 30 days respectively, when compared to control.

The total hydrolysable sugar content was increased in Double Decker calli after 15 days at all tested yeast extract concentrations. After 30 days, the hydrolysable sugar content was increased at 1.0 and $1.5 \mathrm{~g} / \mathrm{l}$ yeast extracts. In both 15 and 30 days, the total hydrolysable sugars recorded the maximum levels (111.9 and $121.9 \mathrm{mg} / \mathrm{g}$ DW respectively) at $1.0 \mathrm{~g} / \mathrm{l}$ yeast extract. While in Rubinstern calli, the total hydrolysable sugars increased with yeast extract levels after 15 days only.
The maximum content $(116.9 \mathrm{mg} / \mathrm{g} \mathrm{DW})$ was obtained at $1.0 \mathrm{~g} / \mathrm{l}$ yeast extract after 30 days. The addition of yeast extract has insignificant effect on total hydrolysable sugar accumulation.

\section{Effect of jasmonic acid}

Regarding the effect of jasmonic acid on the accumulation of active components, data in Table 3 show that caffeic acid derivatives increased significantly in Double Decker calli after 15 days with 50 and $100 \mathrm{mM}$ of jasmonic acid. The production recorded was $4.08 \mathrm{mg} / \mathrm{g}$ $\mathrm{DW}$, at $50 \mathrm{mM}$ jasmonic acid, and this increase was nearly 5.04-folds compared with the control. While after 30 days, caffeic acid derivatives increased significantly at all jasmonic acid concentrations tested which recorded maximum value $(3.71 \mathrm{mg} / \mathrm{g} \mathrm{DW})$ at $100 \mathrm{mM}$ jasmonic acid, and the increase was nearly 2.4-folds compared with untreated cells. Caffeic acid derivatives in Rubinstern calli also increased significantly with 100 and $200 \mathrm{mM}$ jasmonic acid after 15 days, while after 30 days the highest production was obtained at 50 and $200 \mathrm{mM}$ jasmonic acid. The maximum value of caffeic

Table 2 Effect of various concentrations of yeast extract on the caffeic acid derivatives and total hydrolysable sugar contents of Double Decker and Rubinstern calli after 15 and 30 days of cultivation

\begin{tabular}{|c|c|c|c|c|c|c|c|c|c|}
\hline \multirow[t]{2}{*}{ Var. } & \multirow[t]{2}{*}{ YE $(g / l)$} & \multicolumn{2}{|c|}{ Caffeic acid derivatives (mg/g DW) } & \multicolumn{2}{|c|}{ Increases or decreases (\%) } & \multicolumn{2}{|c|}{ Total hydrolysable sugars (mg/g DW) } & \multicolumn{2}{|c|}{ Increases or decreases (\%) } \\
\hline & & 15 days & 30 days & 15 days & 30 days & 15 days & 30 days & 15 days & 30 days \\
\hline \multirow{4}{*}{$\begin{array}{l}\text { Double } \\
\text { Decker }\end{array}$} & 0 & $0.81^{c}$ & $1.69^{c}$ & 0 & 0 & $83.1^{\mathrm{C}}$ & $90.0^{b}$ & 0 & 0 \\
\hline & 0.5 & $1.70^{\mathrm{b}}$ & $3.45^{\mathrm{b}}$ & +0.09 & +0.18 & $106.3^{\mathrm{ab}}$ & $86.3^{b}$ & +2.3 & -0.4 \\
\hline & 1.0 & $2.32^{\mathrm{a}}$ & $3.60^{\mathrm{ab}}$ & +0.15 & +0.19 & $111.9^{\mathrm{a}}$ & $121.9^{\mathrm{a}}$ & +2.9 & +3.2 \\
\hline & 1.5 & $2.38^{\mathrm{a}}$ & $3.66^{\mathrm{a}}$ & +0.16 & +0.20 & $102.5^{b}$ & $118.1^{a}$ & +2.0 & +2.8 \\
\hline $\mathrm{LSD}_{0.05}$ & & 0.20 & 0.17 & & & 7.20 & 9.75 & & \\
\hline \multirow[t]{4}{*}{ Rubinstern } & 0 & $0.59^{c}$ & $0.88^{d}$ & 0 & 0 & $73.4^{c}$ & $123.1^{a}$ & 0 & 0 \\
\hline & 0.5 & $1.41^{b}$ & $1.27^{c}$ & +0.08 & +0.04 & $95.1^{b}$ & $111.9^{b}$ & +2.2 & -1.1 \\
\hline & 1.0 & $1.87^{\mathrm{a}}$ & $2.26^{a}$ & +0.11 & +0.14 & $116.9^{a}$ & $122.5^{a}$ & +4.4 & 0 \\
\hline & 1.5 & $1.49^{b}$ & $2.13^{b}$ & +0.09 & +0.12 & $110.0^{a}$ & $46.9^{d}$ & +3.7 & -7.6 \\
\hline $\mathrm{LSD}_{0.05}$ & & 0.08 & 0.05 & & & 8.79 & 7.88 & & \\
\hline
\end{tabular}


Table 3 Effect of various concentrations of jasmonic acid on the caffeic acid derivatives and total hydrolysable sugar contents of Double Decker and Rubinstern calli after 15 and 30 days of cultivation

\begin{tabular}{|c|c|c|c|c|c|c|c|c|c|}
\hline \multirow[t]{2}{*}{ Var. } & \multirow[t]{2}{*}{$\mathrm{JA}(\mathrm{mM})$} & \multicolumn{2}{|c|}{ Caffeic acid derivatives (mg/g DW) } & \multicolumn{2}{|c|}{ Increases or decreases (\%) } & \multicolumn{2}{|c|}{ Total hydrolysable sugars (mg/g DW) } & \multicolumn{2}{|c|}{ Increases or decreases $(\%$} \\
\hline & & 15 days & 30 days & 15 days & 30 days & 15 days & 30 days & 15 days & 30 days \\
\hline \multirow[t]{4}{*}{ Double Decker } & 0 & $0.81^{c}$ & $1.57^{c}$ & 0 & 0 & $76.9^{b}$ & $90.0^{b}$ & 0 & 0 \\
\hline & 50 & $4.08^{\mathrm{a}}$ & $3.04^{b}$ & +0.33 & +0.14 & $125.7^{\mathrm{a}}$ & $98.3^{\mathrm{b}}$ & +4.9 & +0.8 \\
\hline & 100 & $3.00^{\mathrm{b}}$ & $3.71^{\mathrm{a}}$ & +0.22 & +0.21 & $119.9^{\mathrm{a}}$ & $120.7^{\mathrm{a}}$ & +4.3 & +3.7 \\
\hline & 200 & $0.95^{c}$ & $2.97^{\mathrm{b}}$ & +0.02 & +0.14 & $110.4^{\mathrm{a}}$ & $112.5^{\mathrm{a}}$ & +3.7 & +2.3 \\
\hline $\mathrm{LSD}_{0.05}$ & & 0.30 & 0.20 & & & 15.90 & 11.55 & & \\
\hline \multirow[t]{4}{*}{ Rubinstern } & 0 & $3.59^{b}$ & $3.85^{\mathrm{c}}$ & 0 & 0 & $73.4^{c}$ & $123.1^{\mathrm{a}}$ & 0 & 0 \\
\hline & 50 & $1.76^{c}$ & $7.67^{\mathrm{b}}$ & -0.18 & +0.38 & $161.3^{\mathrm{a}}$ & $129.4^{\mathrm{a}}$ & +8.8 & +0.6 \\
\hline & 100 & $7.25^{\mathrm{a}}$ & $4.05^{c}$ & +0.37 & +0.01 & $123.4^{b}$ & $98.8^{b}$ & +5.0 & -2.4 \\
\hline & 200 & $6.83^{\mathrm{a}}$ & $9.75^{\mathrm{a}}$ & +0.32 & 0.59 & $121.3^{b}$ & $96.9^{b}$ & +4.8 & -2.6 \\
\hline $\mathrm{LSD}_{0.05}$ & & 0.43 & 0.67 & & & 10.51 & 16.03 & & \\
\hline
\end{tabular}

Mean values with the same letter are not significant

acid derivatives after 15 days was $7.25 \mathrm{mg} / \mathrm{g} \mathrm{DW}$ at $100 \mathrm{mM}$ jasmonic acid and $9.75 \mathrm{mg} / \mathrm{g} \mathrm{DW}$ at $200 \mathrm{mM}$ jasmonic acid after 15 and 30 days respectively. The increase reached 2.0- and 2.5-folds after 15 and 30 days respectively compared with untreated cells, while total hydrolysable sugars increased significantly with all tested jasmonic acid concentrations in Double Decker calli after 15 days, but there were no significant differences among treatments. The maximum value of total hydrolysable sugars recorded was $125.7 \mathrm{mg} / \mathrm{g} \mathrm{DW}$ at $50 \mathrm{mM}$ jasmonic acid (the increase nearly 1.6 -fold compared with untreated cells). After 30 days, total hydrolysable sugars increased significantly with 100 and $200 \mathrm{mM}$ of jasmonic acid, and the maximum value observed was $120.7 \mathrm{mg} / \mathrm{g}$ DW at $100 \mathrm{mM}$ jasmonic acid. For Rubinstern calli, total hydrolysable sugars increased significantly with all jasmonic acid concentrations after 15 days, which recorded $161.3 \mathrm{mg} / \mathrm{g} \mathrm{DW}$ at $50 \mathrm{mM}$ jasmonic acid. However, after 30 days, all tested jasmonic acid concentrations were ineffective (or minimized) in total hydrolysable sugar accumulation.

\section{Effect of precursor's feeding on the active components} Phenylalanine and tyrosine were used to increase caffeic acid derivatives and total hydrolysable sugars in Double Decker and Rubinstern Echinacea calli.

\section{Effect of phenylalanine}

Results in Table 4 indicate that increasing phenylalanine concentration increased caffeic acid derivative content in calli of the two varieties, up to $100 \mathrm{mg} / \mathrm{l}$ phenylalanine which then declined. The maximum caffeic acid derivative content $(8.20 \mathrm{mg} / \mathrm{g}$ DW) was recorded in Double Decker variety at $100 \mathrm{mg} / \mathrm{l}$ phenylalanine. This represented a 14.4-fold increase compared with the control. Similarly, at the same level of phenylalanine, Rubinstern variety gave the highest content of caffeic acid derivative $(5.58 \mathrm{mg} / \mathrm{g} \mathrm{DW})$; this represented almost a 6.3-fold increase compared with

Table 4 Effect of various concentrations of phenylalanine on the total caffeic acid derivatives and total hydrolysable sugars of Double Decker and Rubinstern calli after 3 months of cultivation

\begin{tabular}{llll}
\hline Varieties & Phenylalanine conc. (mg/l) & Total caffeic acid derivative conc. (mg/g DW) & Total hydrolysable sugar conc. (mg/g DW) \\
\hline Double Decker & 0 & $0.57^{\mathrm{d}}$ & $69.2^{\mathrm{b}}$ \\
& 50 & $4.62^{\mathrm{b}}$ & $74.6^{\mathrm{b}}$ \\
& 100 & $8.20^{\mathrm{a}}$ & $85.1^{\mathrm{a}}$ \\
& 150 & $0.78^{\mathrm{c}}$ & $71.9^{\mathrm{b}}$ \\
& & 0.19 & 7.05 \\
LSD $_{0.05}$ & 0 & $0.88^{\mathrm{d}}$ & $73.4^{\mathrm{c}}$ \\
Rubinstern & 50 & $2.55^{\mathrm{b}}$ & $95.8^{\mathrm{a}}$ \\
& 100 & $5.58^{\mathrm{a}}$ & $66.3^{\mathrm{d}}$ \\
& 150 & $2.30^{\mathrm{c}}$ & $82.1^{\mathrm{b}}$ \\
& & 0.19 & 6.98 \\
\hline LSD & & &
\end{tabular}


the control. Also, there were significant differences observed between control and all the treatments for the two varieties.

The present data showed that the addition of $100 \mathrm{mg} / \mathrm{l}$ of phenylalanine to Double Decker calli significantly increased the total hydrolysable sugars $(85.1 \mathrm{mg} / \mathrm{g} \mathrm{DW})$. The other treatments (50 and $150 \mathrm{mg} / \mathrm{l}$ ) of phenylalanine slightly increased total hydrolysable sugars. While in Rubinstern calli, addition of phenylalanine at $50 \mathrm{mg} / \mathrm{l} \mathrm{re-}$ corded the highest content of total hydrolysable sugars ( $95.8 \mathrm{mg} / \mathrm{g}$ DW).

Generally, the addition of phenylalanine in low levels to the culture media has stimulatory effect on the accumulation of total hydrolysable sugars including polysaccharides while higher levels have a negative effect on the contents of hydrolysable sugars.

\section{Effect of tyrosine}

Data in Table 5 revealed that the caffeic acid derivative content increased with all tyrosine concentrations in Double Decker calli. Caffeic acid derivatives recorded the highest contents $(2.67 \mathrm{mg} / \mathrm{g} \mathrm{D} . W$.$) at 50 \mathrm{mg} / \mathrm{l}$ tyrosine. For Rubinstern calli, the caffeic acid derivatives increased gradually with increasing tyrosine level until it reached the maximum value $(8.41 \mathrm{mg} / \mathrm{g} \mathrm{DW})$ at $150 \mathrm{mg} / \mathrm{l}$ tyrosine and this value was nearly 9.55 times greater than the control.

With regard to hydrolysable sugars, the highest contents of total hydrolysable sugars $(90 \mathrm{mg} / \mathrm{g} \mathrm{DW})$ were recorded in Double Decker calli by the addition of $150 \mathrm{mg} / \mathrm{l}$ tyrosine while, in Rubinstern calli, addition of only $50 \mathrm{mg} / \mathrm{l}$ tyrosine gave the highest value $(93.8 \mathrm{mg} / \mathrm{g}$ DW). Also, it was observed that there were significant differences between the control and two treatments of tyrosine $(50$ and $100 \mathrm{mg} / \mathrm{l})$.

Hence, it could be concluded that tyrosine has a positive effect on the accumulation of caffeic acid derivatives in
Double Decker and Rubinstern calli. Higher levels of tyrosine resulted in maximum accumulation of hydrolysable sugars in Double Decker variety, while in Rubinstern variety higher levels of tyrosine have a negative effect on the accumulation of total hydrolysable sugars.

\section{Biological studies}

This part of study aims to examine the activity of the active compounds produced by in vitro cultures (in vitro plants and callus cultures) as antioxidant, antitumor and antimicrobial agents compared with in vivo plants of Rubinstern and Double Decker varieties.

\section{DPPH radical scavenging capacity \% (RSC\%)}

Table 6 shows different radical scavenging capacity (RSC\%) of various Echinacea extracts at different reaction times (15, 30, 45 and $60 \mathrm{~min})$. Data indicate that all Echinacea extracts exhibited radical scavenging capacity. The maximum value of RSC\% (92.8\%) was recorded with the extract of in vitro Double Decker plant after $45 \mathrm{~min}$, followed by the same extract after $60 \mathrm{~min}$ (90.4\%), whereas the minimum value $(75.7 \%)$ of $\mathrm{RSC} \%$ after 45 min was recorded by the extract of in vivo Rubinstern plant and after $60 \mathrm{~min}$ by the extract of in vitro Rubinstern plant (77.9\%). It was recorded that the RSC\% of all Echinacea extracts was low after 15 and $30 \mathrm{~min}$ and then increased after $45 \mathrm{~min}$, but after $60 \mathrm{~min}$, some Echinacea extracts were increased and others were decreased.

\section{Cytotoxic effect of Echinacea extracts}

In this experiment, different Echinacea extracts were tested against Ehrlich Ascites Carcinoma Cell (EACC) line. Data in Fig. 3 indicate that incubation of cancer cells with the tested extracts $(2 \mathrm{~h})$ affected the viability of tumor cells. The maximum number of cell deaths were observed with the extract of Rubinstern Echinacea calli (78.2\%) followed by Double Decker Echinacea calli

Table 5 Effect of various concentrations of tyrosine on the total caffeic acid derivatives and total hydrolysable sugars contents of Double Decker and Rubinstern calli after three months of cultivation

\begin{tabular}{llll}
\hline Varieties & Tyrosine conc. (mg/l) & Total caffeic acid derivative conc. (mg/g DW) & Total hydrolysable sugar conc. (mg/g DW) \\
\hline Double Decker & 0 & $0.57^{\mathrm{d}}$ & $69.2^{\mathrm{b}}$ \\
& 50 & $2.67^{\mathrm{a}}$ & $86.3^{\mathrm{a}}$ \\
& 100 & $1.72^{\mathrm{c}}$ & $85.0^{\mathrm{a}}$ \\
& 150 & $2.22^{\mathrm{b}}$ & $90.0^{\mathrm{a}}$ \\
& & 0.16 & 5.55 \\
LSD 0.05 & $0.88^{\mathrm{d}}$ & $73.4^{\mathrm{b}}$ \\
Rubinstern & 0 & $2.33^{\mathrm{c}}$ & $93.8^{\mathrm{a}}$ \\
& 50 & $3.45^{\mathrm{b}}$ & $85.7^{\mathrm{a}}$ \\
& 100 & $8.41^{\mathrm{a}}$ & $70.0^{\mathrm{b}}$ \\
& 150 & 0.05 & 10.95 \\
\hline LSD 0.05 & & & \\
\hline
\end{tabular}


Table 6 Percentage of radical scavenging capacity (RSC\%) of DPPH by different extracts of in vivo and in vitro Echinacea plants as well as callus extracts at different times

\begin{tabular}{lllll}
\hline \multirow{2}{*}{$\begin{array}{l}\text { Echinacea } \\
\text { extracts }\end{array}$} & \multicolumn{4}{l}{ Antioxidant activity \% } \\
\cline { 2 - 5 } & $15 \mathrm{~min}$ & $30 \mathrm{~min}$ & $45 \mathrm{~min}$ & $60 \mathrm{~min}$ \\
\hline In vivo plants & & & & \\
$\quad$ Double Decker & 36.6 & 62.5 & 76.5 & 79.1 \\
$\quad$ Rubinstern & 34.5 & 65.7 & 75.7 & 78.9 \\
$\begin{array}{l}\text { In vitro plants } \\
\text { Double Decker }\end{array}$ & 43.2 & 79.1 & 92.8 & 90.4 \\
$\quad$ Rubinstern & 47.0 & 70.5 & 79.3 & 77.9 \\
Callus & & & & \\
$\quad$ Double Decker & 67.7 & 76.9 & 86.3 & 86.9 \\
$\quad$ Rubinstern & 67.1 & 65.1 & 76.9 & 89.2 \\
\hline
\end{tabular}

extract $(62.0 \%)$. The cell death (\%) was higher with the extract of in vivo Double Decker Echinacea plant (59.4\%) compared with the extract of in vivo Rubinstern Echinacea plant (53.9\%), as well as in the in vitro Echinacea plants. On the other hand, the extract of Rubinstern Echinacea calli was better than Double Decker Echinacea calli for inducing cell death.

\section{Antimicrobial activity of Echinacea extracts}

Different Echinacea extracts including in vivo plants, in vitro plants and callus of Rubinstern and Double Decker varieties were tested against Bacillus subtilis-NRRL-B941(G +), S. aureus (G+), E. coli-NRR-B3704(G-), and two strains of yeasts (S. cerevisiae and C. albicans). About $200 \mu \mathrm{l}$ of
Table 7 Antimicrobial activity of different Echinacea extracts as inhibition zone diameters

\begin{tabular}{lllllll}
\hline Microbial cultures & \multicolumn{7}{l}{ Inhibition zone diameters $(\mathrm{cm})$} \\
\cline { 2 - 7 } & 1 & 2 & 3 & 4 & 5 & 6 \\
\hline Bacillus subtilis & 2.5 & 2.0 & 3.0 & 3.0 & 1.5 & 3.0 \\
Staphylococcus aureus & 2.5 & 1.7 & 2.0 & 0.0 & 1.5 & 2.0 \\
Escherichia coli & 0.5 & 2.0 & 0.0 & 1.5 & 0.0 & 1.5 \\
Saccharomyces cerevisiae & 3.0 & 2.0 & 0.0 & 1.5 & 0.0 & 1.8 \\
Candida albicans & 2.5 & 0.0 & 0.0 & 3.0 & 0.0 & 0.0 \\
\hline
\end{tabular}

(1) In vivo Double Decker plant, (2) In vivo Rubinstern plant, (3) In vitro Double Decker plant, (4) In vitro Rubinstern plant, (5) Callus of Double Decker, (6)

Callus of Rubinstern

each extract was loaded in sterile plates, and the inhibitory effect was observed by measuring the inhibition zone diameter $(\mathrm{cm})$.

The data in Table 7 indicate that all Echinacea extracts showed inhibitory effect against Bacillus subtilis. The extracts of in vitro Double Decker and Rubinstern plants recorded inhibition zone $(3 \mathrm{~cm})$ higher than those recorded by the extract of in vivo plants. The lowest inhibition zone diameter $(1.5 \mathrm{~cm})$ was recorded with the extract of Double Decker calli (Fig. 4).

All Echinacea extracts inhibited the growth of $S$. aureus except the extracts of in vitro Rubinstern plant. The highest inhibition zone $(2.5 \mathrm{~cm})$ was recorded with the extracts of in vivo Double Decker plant. The inhibition zone of the in vivo Double Decker plant extract was higher than that of the same in vitro variety (Fig. 4). The inhibition zone for E. coli was observed with all Echinacea extracts except the

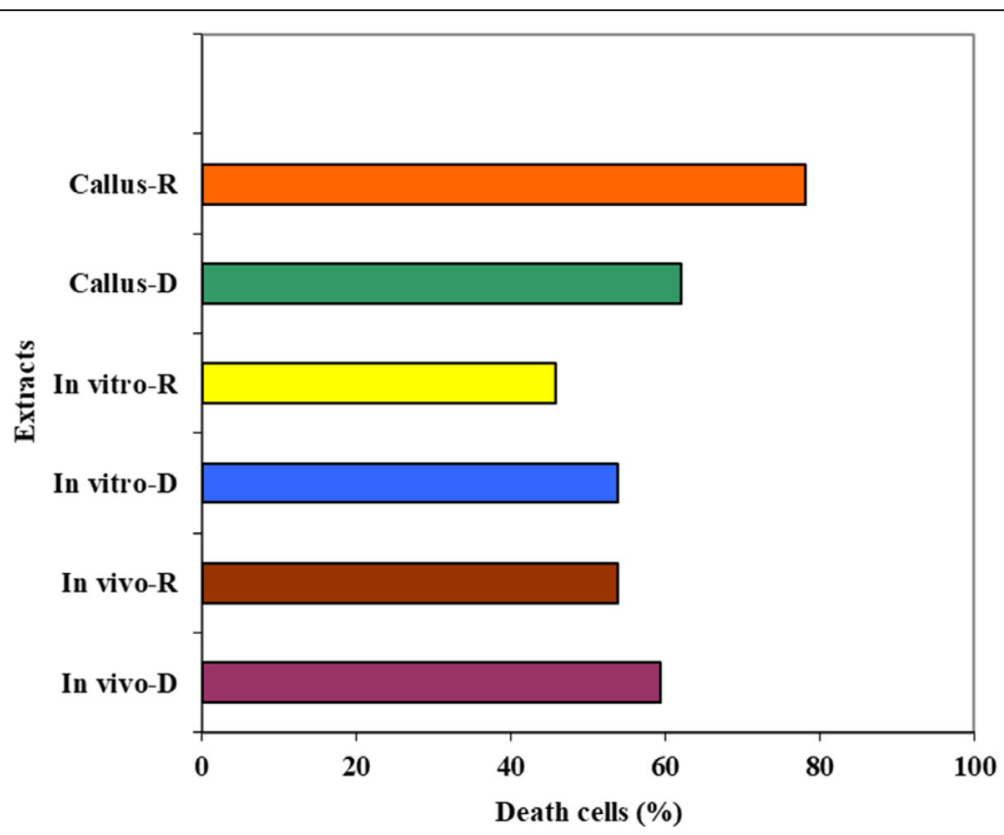

Fig. 3 Percentage of cells death in EACC by different Echinacea extracts. $R=$ Rubinstern variety and $D=$ Double Decker variety 

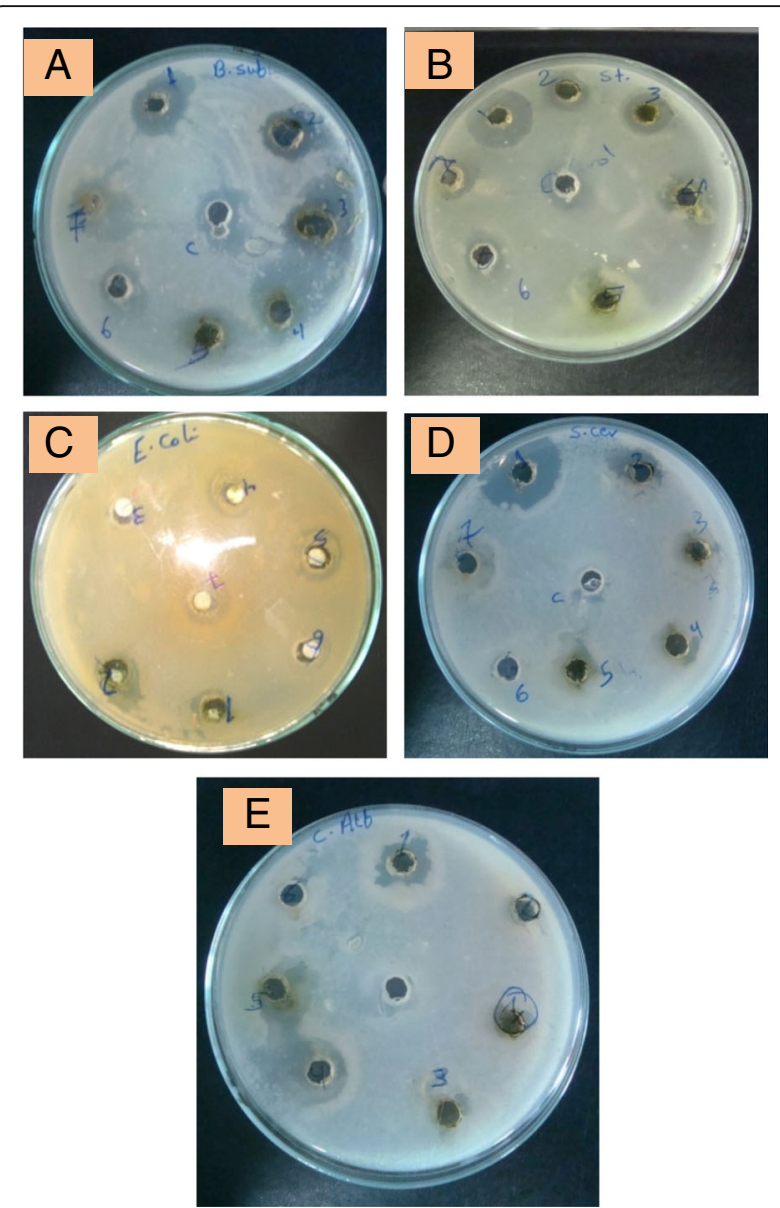

Fig. 4 Inhibition zone diameters of different Echinacea extracts against tested microbes. a Bacillus subtilis. b Staphylococcus aureus. c Escherichia coli. d Saccharomyces cerevisiae. e Candida albicans

extracts of in vitro plant and callus of Double Decker variety. The highest inhibition zone diameter was recorded with the extract of in vivo Rubinstern plant $(2.0 \mathrm{~cm})$, while the lowest inhibition zone $(0.5 \mathrm{~cm})$ was recorded with the extract of in vivo Double Decker plant (Fig. 4).

Inhibition zone for S. cerevisiae with different Echinacea extracts were observed with all extracts except the extracts of in vitro plant and callus of Double Decker variety. The highest inhibition zone was recorded with in vivo Double Decker extract $(3.0 \mathrm{~cm})$ and the minimum value $(1.5 \mathrm{~cm})$ was observed with in vitro Rubinstern plant (Fig. 4). The inhibitory effect of different Echinacea extracts against $C$. albicans revealed that most Echinacea extracts did not show inhibitory effect against $C$. albicans except two extracts including in vivo Double Decker and in vitro Rubinstern plants (3.0 and $2.5 \mathrm{~cm}$, respectively).

From these results, it could be concluded that, among the investigated extracts, different Echinacea extracts show moderate activity against tested microbial strains.

\section{Discussions}

Some studies achieved the initiation and production of callus from Echinacea species using different combinations of growth regulators. Koroch et al. (2002) showed that leaf explants of E. purpurea cultured on basal medium with different combinations of BA and NAA induced callus formation after 4 weeks of cultivation. Also, Lucchesini et al. (2009) found that white friable calli induced on media containing NAA and BA from leaf explants of E. angustifolia developed to shoot regeneration. Furthermore, Zayova et al. (2012a) found that the highest amount of callus (90\%) was produced on MS medium containing $0.5 \mathrm{mg} / \mathrm{l} \mathrm{BA}$ and $1 \mathrm{mg} / \mathrm{l} \mathrm{NAA}$ from leaf explants of $E$. purpurea seedling after 3 weeks of cultivation. Our results are in agreement with these studies, where it was observed that all combinations of NAA and BA induced calli from both explants (leaf and shoot-tip) with the two Echinacea varieties after 4 weeks of cultivation.

The use of biotic and abiotic elicitors to stimulate the formation of natural product has become an important progress strategy and have been proved very useful in reducing the process time required to attain high concentrations of product and increased productivity (Dornenburg 2004). Yeast extract did not affect the biosynthesis pathway of plants but it triggered the production of endogenous jasmonic acid and/or methyl jasmonate which influence the production of secondary metabolites (Sánchez-Sampedro et al. 2005). For example, Li and Barz (2005) reported that the elicitation of cell culture of $E$. purpurea with yeast extract produced two new 8,4' -oxynorneoligans that were not detected in the intact plants and have cytotoxicity in human tumor cells. Yan et al. (2006) found that the root of Salvia miltiorrhiza treated with $200 \mathrm{mg} / \mathrm{l}$ yeast extract for 4 and 8 days increased rosmarinic acid content by 1.5- and 1.6-folds compared with control. Furthermore, the total phenolic content of roots treated by $200 \mathrm{mg} / \mathrm{l}$ yeast extract was about $20 \%$ higher than that of the control. Also, Cakir and Ari (2009) found that, in yeast extract, treated cell cultures of Astragalus chrysochlorus increased the total phenolic content after $24 \mathrm{~h}$. Also, the addition of yeast extract to the shoot culture medium of Curcuma mangga increased the total phenolic content only up to the certain level $(3.5 \mathrm{mg} / \mathrm{l})$ (Abraham et al. 2011).

In the present study, addition of 1.0 or $1.5 \mathrm{~g} / \mathrm{l}$ yeast extract to callus cultures resulted in increasing caffeic acid content, the increase was between 2.16- and 3.2-fold increase with the two varieties used. However, using yeast extract has insignificant effect on total hydrolysable sugars. The highest hydrolysable sugar increment recorded was with $1.0 \mathrm{~g} / \mathrm{l}$ yeast extract.

Generally, it is reported that yeast extract enhances the accumulation of caffeic acid derivatives in Echinacea 
calli (Sánchez-Sampedro et al. 2005). However, in our study, the highest hydrolysable sugar increment recorded was with $1.0 \mathrm{~g} / \mathrm{l}$ yeast extract treatment in Double Decker calli after 30 days while in Rubinstern calli it was after 15 days.

The stimulation effect of jasmonic acid on the accumulation of phenolic compounds is reported by Kim et al. (2006) who found that total phenolic contents of the sweet basil treated with 0.1 and $0.5 \mathrm{mM}$ methyl jasmonate (MeJA) reached maximal values at the second day after the treatment. The increase recorded was $27 \%$ and $57 \%$, respectively, higher than that of the control harvested on the same day. Horbowicz et al. (2011) exposed seedling of buckwheat (Fagopyrumes culentum Moench) to MeJA vapor and reported that MeJA stimulated the accumulation of the total phenolics in cotyledons and hypocotyls. Hence, it could be concluded that MeJA probably stimulated the production of various derivatives of phenolic acids. Also, Nafie et al. (2011) found that $0.5,5$ and $10 \mu \mathrm{mol}$ concentrations of Jasmonic acid were effective for increasing phenylalanine ammonia-lyase (PAL) activity over the control in melon cell suspension. Furthermore, addition of Jasmonic acid or methyl jasmonate to Mentha piperita suspension cultures resulted in high accumulation of phenolic compounds (Krzyzanowska et al. 2012). Recently, Kikowska et al. (2015) reported the optimum condition of elicitation for cultivation of shoots of Eryngium planum in liquid MS media in the presence of $100 \mu \mathrm{M}$ MeJA for $48 \mathrm{~h}$. This resulted in an approximately 4.5 -fold increase in rosmarinic, chlorogenic and caffeic acid in plant material compared with the control. The results in the present study revealed that addition of jasmonic acid caused an increase in caffeic acid and total sugar content of the cultures used. The increment was between 1.6and 2.5-folds compared with untreated cultures.

The aromatic amino acids, phenylalanine and tyrosine, form the basis of $\mathrm{C}_{6}-\mathrm{C}_{3}$ phenylpropane units through the shikimate pathway (the pathway provides many aromatic compounds in plants including caffeic acid derivatives). In this respect, it was reported that L-phenylalanine has a stimulatory role on the accumulation of phenolics in cultures of Spirulina maxima algae (Abd El-Baky et al. 2009). Moreover, Hegazi and El-Lamey (2011) found that the chlorogenic acid of Ephedra alata callus cultures gave the highest amount in a medium containing $100 \mathrm{mg} / \mathrm{l} \mathrm{L}$-phenylalanine. Roy and Mukhopadhyay (2012) found that total phenolic content of Mentha arvensis shoot cultures augmented up to $5.31 \mathrm{mg} / \mathrm{g} F W$ after addition of $10 \mathrm{mg} / \mathrm{l}$ phenylalanine (nearly 2.25 times higher than the control plants). They added that higher concentration of phenylalanine did not favor increment in total phenol content. This finding agreed with our results which showed that higher levels of phenylalanine (more than $100 \mathrm{mg} / \mathrm{l}$ ) reduced the content of caffeic acid derivatives in calli of the two varieties.

In a previous study, Guo et al. (2012) found that addition of $2 \mathrm{mM}$ phenylalanine in callus cultures of Glycyrrhiza uralensis gave a high polysaccharide content (9.9\%). El-Naggar (2012) showed that higher levels of tyrosine enhanced phenylalanine ammonia-lyase (PAL) gene activity (it is the enzyme at the entry point of the phenylpropanoid pathway, which yields a variety of phenolic compounds). This observation disagreed with our results in the case of Double Decker calli; hence, the lowest level of tyrosine was more effective but it agreed with that in Rubinstern calli. However, Sabra et al. (2012) reported that phytochemical profile of caffeic acid derivatives, alkamides and/or ketones was not affected by salinity (as a biotic elicitor). However, significant changes in their relative amount were found depending on the Echinacea species and salinity intensity.

Several studies were focused on the antioxidant activity of Echinacea species. Hu and Kitts (2000) reported that the antioxidants of E. purpurea are due to echinacoside and caffeic acid which have potent scavengers of free radicals such as hydroxyl radicals and superoxide. Also, Sloley et al. (2001) evaluated the antioxidant activity of Echinacea roots and leaves using the $2,2^{\prime}$-azino-bis (3-ethylbenzothiazoline-6-sulfonic acid) (ABTS.) radical cation model. They found a correlation between the methanolic extract composition and the antioxidant activity. From these results, it could be concluded that all tested Echinacea extracts expressed a free radical scavenging capacity (RSC). These findings are in accordance with the published data by Pellati et al. (2004) who reported that the DPPH scavenging activity was high in E. purpurea and decreased in E. pallida and E. angustifolia. The values of the DPPH radical scavenging activity showed positive correlation with those of total phenolics.

Antioxidant activities of extracts from E. purpurea derived from in vitro propagated plants and adapted to field conditions in comparison to the extracts from traditionally cultivated plants were compared by Zayova et al. (2012b). They found that water-soluble and lipid-soluble antioxidant capacities increased threefolds or more but total phenolic content increased by only 9\%. Elevated levels of antioxidant components determined higher radical scavenging activity. Therefore, total antioxidant potential also increased by $27 \%$ in comparison with traditionally cultivated plants.

Carlo et al. (2003) reported that E. purpurea extracts have anti-apoptotic activity through upregulation of $\mathrm{BCl}_{2}$ and downregulation of Fas. Also, Huntimer et al. (2006) reported that Echinacea herbal medicines affect cell proliferation despite cancer treatment. In this connection, Sayed (2011) reported that mice treated with combined 
doses of Echinacea extract and cisplatin (inorganic antitumor drug) showed pronounced significant increases in percentages of polychromatic erythrocytes (PCEs).

Sharma et al. (2008) examined six different commercial Echinacea extracts for their ability to inactivate 15 different human pathogenic bacteria and two pathogenic fungi. They found that five bacteria were very sensitive to one or more of the extracts. The other bacteria and fungi were either slightly sensitive to one or more extracts or were totally resistant. Candida albicans was previously reported as sensitive to Echinacea by Merali et al. (2003). No common mechanism of antibacterial activity was found, since Echinacea is part of the Asteraceae family, which is known to contain many plants rich in antibacterial polyenes and thiophenes; such compounds might also have contributed to the activities observed (Hudson 2010). Our results confirmed the inhibitory effect of different Echinecea extracts used in this study with results of most studies. In the present study, it was found that all Echinacea extracts showed inhibitory effect against Bacillus subtilis and some extracts inhibited the growth of S. aureus. However, different Echinacea extracts showed an inhibition zone for Saccharomyces cervisiae. Also, most extracts did not show an inhibitory effect against $C$. albicans.

\section{Conclusion}

Caffeic acid derivatives and polysaccharides are the principal phytochemical constituents of Echinacea extracts. Cell culture system is a tool for the large-scale culture of plant cells, which produce a continuous source of secondary metabolites. The synthesis of secondary metabolites in cell cultures can be induced and enhanced by some strategies including precursors feeding and elicitor's treatment. Therefore, this study was conducted to enhance the production of major secondary metabolites (caffeic acid derivatives and total hydrolysable sugars) of callus culture of two Echinacea varieties. Two elicitors (yeast extract and jasmonic acid) and two precursors (phenylalanine and tyrosine) were used to achieve this goal. Among different treatments, the application of jasmonic acid as elicitor with Rubinstern calli attained maximum caffeic acid derivatives $(9.75 \mathrm{mg} / \mathrm{g} \mathrm{DW})$ and total hydrolysable sugars (161.3 mg/g DW). Also, Rubinstern calli recorded maximum antioxidant and cytotoxic activities. For antibacterial activity, most Echinacea extracts showed an inhibitory effect against tested microbes.

\section{Acknowledgements}

The authors are greatly indebted to the National Research Centre for the generous financing support that enables us to achieve this work.

\section{Funding}

Financial support made by National Research Centre, Egypt, is gratefully acknowledged.

\section{Availability of data and materials}

The datasets used and/or analysed during the current study are available from the corresponding author on reasonable request.

\section{Authors' contributions \\ All authors participated in the development and implementation of the research plan and subsequently written it. All authors read and approved the final manuscript.}

Ethics approval and consent to participate

Not applicable

Consent for publication

Not applicable

\section{Competing interests}

The authors declare that they have no competing interests.

\section{Publisher's Note}

Springer Nature remains neutral with regard to jurisdictional claims in published maps and institutional affiliations.

\section{Author details}

${ }^{1}$ Plant Biotechnology Department, National Research Centre, P.O. 12622, Dokki, Giza, Egypt. 2Biochemistry Department, Faculty of Agriculture, Cairo University, Giza, Egypt.

Received: 8 August 2018 Accepted: 15 October 2018

Published online: 09 November 2018

\section{References}

Abbasi BH, Saxena PK, Murch SJ, Liu CZ (2007) Echinacea biotechnology: challenges and opportunities. In Vitro Cell Dev Biol-Plant 43:481-492

Abd El-Baky HH, El-Baz FK, El-Baroty GS (2009) Production of phenolic compounds from Spirulina maxima microalgae and its protective effects in vitro toward hepatotoxicity model. Afr J Pharm Pharmacol 3:133-139

Aboul-Enein AM, Afify AEM, Rady MR, Hendawy SF, Ibrahim MM (2013) In vitro clonal propagation, caffeic acid production and RAPD analysis of some varieties of Echinacea purpurea plant. J Appl Sci Res 1:843-851

Abraham F, Bhatt A, Keng CL, Indrayanto G, Sulaiman SF (2011) Effect of yeast extract and chitosan on shoot proliferation, morphology and antioxidant activity of Curcuma manggain vitro plantlets. Afr J Biotechnol 10:7787-7795

Barrett B (2003) Medicinal properties of Echinacea: a critical review. Phytomedicine 10:66-86

Bauer R (1998) Echinacea: biological effects and active principles. In: Lawson LD, Bauer R (eds) Phytomedicines of Europe: chemistry and biological activity. ACS press Inc, Washington, pp 140-157

Bauer R (1999) Standardization of Echinacea purpurea expressed juice with reference to cichoric acid and alkamides. J Herbs Spices Med Plants 6:51-62

Bauer R, Remiger P, Wagner H (1988) Alkamides from the roots of Echinacea purpurea. Phytochemistry 27:2339-2342

Bennett JM, Catovsky D, Danicl NIT, Flanclrin G, Galton DAG (1976) Proposal for the classification of the acute myleloid leukemia. Br J Haematol 33:451-458

Bergeron C, Gafner S, Batch LL, Angerhofer K (2002) Stabilization of caffeic acid derivatives in Echinacea purpurea L. glycerin extract. J Agric Food Chem 5: 3967-3970

Binns SE, Purgina B, Bergeron C, Smith ML, Ball L, Baum BR, Arnason JT (2000) Light-mediated antifungal activity of Echinacea extracts. Planta Med 66:241244

Brand-Williams W, Cuvelier ME, Berset C (1995) Use of a free radical method to evaluate antioxidant activity. Lebenson Wiss Technol 28:25-30

Briskin DB (2000) Medicinal plants and phytomedicines. Linking plant biochemistry and physiology to human health. Plant Physiol 124:507-514

Cakir O, Ari S (2009) Defensive and secondary metabolism in Astragalus chrysochlorus cell cultures in response to yeast extract stressor. J Environ Biol 30:51-55

Carlo GD, Nuzzo I, Capasso R, Sanges MR, Galdiero E, Capasso F, Carratelli CR (2003) Modulation of apoptosis in mice treated with Echinacea and St. John's wort. Pharmacol Res 48:273-777 
Choffe KL, Murch SJ, Saxena PK (2000) Regeneration of Echinacea purpurea: induction of root organogenesis from hypocotyl and cotyledon explants. Plant Cell Tissue Organ Cult 62:227-234

Dornenburg H (2004) Evaluation of immobilization effects on metabolic activities and productivity in plant cell processes. Process Biochem 39:1369-1375

Dubois M, Smith F, Gilles KA, Hamilaton JK, Rebers PA (1956) Calorimetric method for determination of sugars and related substance. Anal Chem 28: 350-356

El-Naggar HM (2012) Phenylalanine ammonia-lyase (PAL) gene activity in response to proline and tyrosine in rosemary callus culture. Afr J Biotechnol 11:159-163

Guo S, Man S, Gao W, Liu H, Zhang L, Xiao P (2012) Production of flavonoids and polysaccharide by adding elicitor in different cellular cultivation processes of Glycyrrhiza uralensis. Acta Physiol Plant 35:679-686

Harrigan WF, Mc-Cance ME (1976) Laboratory methods in food and dairy Microbiology. Academic press, London New York San Francisco

Hegazi GA, El-Lamey TM (2011) In vitro production of some phenolic compounds from Ephedra alata Decne. J Appl Environ Biol Sci 1:158-163

Hobbs CR (1998) The Echinacea handbook. Botanica, Capitola

Horbowicz M, Chrzanowski G, Koczkodaj D, Mitrus J (2011) The effect of methyl jasmonate vapors on content of phenolic compounds in seedlings of common buckwheat (Fagopyrum esculentum MOENCH). Acta Soc Bot Pol 80:5-9

Hu C, Kitts DD (2000) Studies on the antioxidant activity of Echinacea root extract. J Agric Food Chem 48:1466-1472

Hu C, Kitts DD, Zawistowski J (2004) The chemistry of antioxidant constituents of Echinacea. In: Miller S (ed) The genus Echinacea. CRC press, Boca Raton, pp 23-28

Hudson JB (2010) The multiple actions of the phytomedicine Echinacea in the treatment of colds and flu. J Med Plants Res 4:2746-2752

Huntimer ED, Halaweish FT, Chase CL (2006) Proliferative activity of Echinacea angustifolia root extracts on cancer cells: interference with doxorubicin cytotoxicity. Chem Biodivers 3:695-703

Kikowska M, Kędziora I, Krawczyk A, Thiem B (2015) Methyl jasmonate, yeast extract and sucrose stimulate phenolic acids accumulation in Eryngium planum L. Shoot cultures. Acta Biochim Pol 62:197-200

Kim HJ, Chen F, Wang X, Rajapakse NC (2006) Effect of methyl jasmonate on secondary metabolites of sweet basil (Ocimum basilicum L.). J Agric Food Chem 54:2327-2332

Koroch A, Juliani HR, Kapteyn J, Simon JE (2002) In vitro regeneration of Echinacea purpurea from leaf explants. Plant Cell Tissue Organ Cult 69:79-83

Krzyzanowska J, Czubacka A, Pecio L, Przybys M, Doroszewska T, Stochmal A, Oleszek W (2012) The effects of jasmonic acid and methyl jasmonate on rosmarinic acid production in Mentha piperita cell suspension cultures. Plant Cell Tissue Organ Cult 108:73-81

Li TSC (1998) Echinacea: cultivation and medicinal value. Hortechnology 8:122-129

Li WW, Barz W (2005) Biotechnological production of two new 8,4'oxynorneolignans by elicitation of Echinacea purpurea cell cultures. Tetrahedron Lett 46:2973-2972

Lienert D, Anklam E, Panne U (1998) Gas chromatography-mass spectral analysis of roots of Echinacea species and classification by multivariate data analysis. Phytochem Anal 9:88-98

Lin L, Faraco J, Li R, Kadotani H, Rogers W, Lin X, Qiu X, de Jong PJ, Nishino S, Mignot $E$ (1999) The sleep disorder canine narcolepsy is caused by a mutation in the hypocretin (orexin) receptor 2 gene. Cell 98:365-376

Lucchesini M, Bertoli Mensuali-Sodi A, Pistelli L (2009) Establishment of in vitro tissue cultures from Echinacea angustifolia D.C. adult plants for the production of phytochemical compounds. Sci Hortic 122:484-490

Macchia M, Angelini LG, Ceccarini L (2001) Methods to overcome seed dormancy in Echinacea angustifolia DC. Sci Hortic 89:317-324

Merali S, Binns S, Paulin-Levasseur M, Ficker C, Smith M, Baum B, Brovelli E, Arnason JT (2003) Antifungal and anti-inflammatory activity of the genus Echinacea. Pharm Biol 41:412-420

Miller A (2000) Echinacea 2000: technical crop report. Richters: The herb specialists, Goodwood

Misawa M (1994) Equipment and facilities. In: Plant tissue culture: an alternative for production of useful metabolites. Bio. International, Toronto

Murashige T, Skoog F (1962) A revised medium for rapid growth and bio assays with tobacco tissue cultures. Physiol Plant 15:473-497

Nafie E, Hathout T, Al-Mokadem A (2011) Jasmonic acid elicits oxidative defense and detoxification systems in Cucumis melo L. cells. Braz J Plant Physiol 23:161-174
Pellati F, Benvenuti S, Magro L, Melegari M, Soragni F (2004) Analysis of phenolic compounds and radical scavenging activity of Echinacea spp. J Pharm Biomed Anal 35:289-301

Percival SS (2000) Use of Echinacea in medicine. Biochem Pharmacol 60:155-158

Roy D, Mukhopadhyay S (2012) Enhanced rosmarinic acid production in cultured plants of two species of Mentha. Indian J Exp Biol 50:817-825

Sabra A, Adam L, Daayf F, Renault S (2012) Salinity-induced changes in caffeic acid derivatives, alkamides and ketones in three Echinacea species. Environ Exp Bot 77:234-241

Sánchez-Sampedro MA, Fernández-Tárrago J, Corchete P (2005) Yeast extract and methyl jasmonate-induced silymarin production in cell cultures of Silybum marianum (L.). Gaernt. J Biotechnol 119:60-69

Sayed NHM (2011) Investigation of the protective effect of Echinacea extract on cisplatin-induced DNA damage, chromosomal aberrations and micronuclei formation in mice. J Am Sci 7:1234-1239

Sharma M, Vohra S, Arnason JT, Hudson JB (2008) Echinacea extracts contain significant and selective activities against human pathogenic bacteria. Pharm Biol 46:111-116

Sicha JH, Becker H, Dusek J, Hubik J, Siaka T, Hrones I (1991) Callus cultures of the genus Echinacea II. Effect of phenylalanineon the growth of cultures and production of cinnamic acids. Pharmazie 46:363-364

Sloley BD, Urichuk LJ, Tywin C, Coutts RT, Pang PKT, Shan JJ (2001) Comparison of chemical components and antioxidant capacity of different Echinacea species. J Pharm Pharmacol 53:849-857

Waller RA, Duncan DB (1969) A bayes rule for summetric multiple comparisons problems. J Am Stat Assoc 65:1485-1503

Yan Q, Shi M, Ng J, Wu JY (2006) Elicitor-induced rosmarinic acid accumulation and secondary metabolism enzyme activities in Salvia miltiorrhiza hairy roots. Plant Sci 170:853-858

Zayova E, Dimitrova L, Nedev T, Philipov P, Stoeva D (2012a) Organogenesis through callus culture of Echinacea purpurea, Proceedings of the Seventh Conference on Medicinal and Aromatic Plants of Southeast European Countries, (Proceedings of the 7th CMAPSEEC), Subotica, Serbia, pp 326-331

Zayova E, Stancheva I, Geneva M, Petrova M, Vasilevska-Ivanova R (2012b) Morphological evaluation and antioxidant activity of in vitro- and in vivoderived Echinacea purpurea plants. Cent Eur J Biol 7:698-707

\section{Submit your manuscript to a SpringerOpen ${ }^{\odot}$ journal and benefit from:}

- Convenient online submission

- Rigorous peer review

- Open access: articles freely available online

High visibility within the field

- Retaining the copyright to your article

Submit your next manuscript at $\boldsymbol{\nabla}$ springeropen.com 